\title{
Intermédialités
}

Histoire et théorie des arts, des lettres et des techniques

Intermediality

History and Theory of the Arts, Literature and Technologies

\section{Intermedial Products for Digital Natives: British Theatre-Cinema on Italian Screens}

\section{Maddalena Pennacchia}

Numéro 30-31, automne 2017, printemps 2018

cartographier (l’intermédialité)

mapping (intermediality)

URI : https://id.erudit.org/iderudit/1049952ar

DOI : https://doi.org/10.7202/1049952ar

Aller au sommaire du numéro

Éditeur(s)

Revue intermédialités (Presses de l’Université de Montréal)

ISSN

1920-3136 (numérique)

Découvrir la revue

Citer cet article

Pennacchia, M. (2017). Intermedial Products for Digital Natives: British

Theatre-Cinema on Italian Screens. Intermédialités / Intermediality, (30-31).

https://doi.org/10.7202/1049952ar
Résumé de l'article

Le concept d'intermédialité a connu une transformation profonde avec le tournant numérique, qui a provoqué l'amenuisement des différences entre les médias, jusqu'à les rendre virtuelles, et la supplantation d'un système analogique discontinu par un système de communication continu. Est-ce que l'intermédialité fait encore sens à l'ère post-médiatique ? Comment les enfants du numérique la perçoivent-ils avec leurs habiletés cognitives particulières ? Pouvons-nous penser la littérature au sein d'une relation intermédiale fluide avec d'autres médias ? Une telle approche peut-elle contribuer à l'enseignement de la littérature aux enfants du numérique ? Quels sont les produits intermédiaux que les industries culturelles conçoivent spécifiquement pour eux ? Prenant Shakespeare comme exemple éminent d'un écrivain dont l'oeuvre a été adapté pour différents médias, cet article est consacré aux productions théâtrales britanniques qui sont conçues pour être diffusées sur les écrans des cinémas du monde entier. Il présentera à cet effet les résultats d'une expérience lors de laquelle nous avons évalué la réception de ces productions par un échantillon d'adolescents italiens.
Ce document est protégé par la loi sur le droit d'auteur. L'utilisation des services d'Érudit (y compris la reproduction) est assujettie à sa politique d'utilisation que vous pouvez consulter en ligne.

https://apropos.erudit.org/fr/usagers/politique-dutilisation/ 


\title{
Intermedial Products for Digital Natives: British Theatre-Cinema on Italian Screens
}

\author{
Maddalena Pennacchia
}

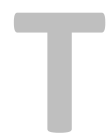

he concept of intermediality underwent a deep transformation with the digital turn, when the difference between media became entirely virtual and a continuous communication system superseded the discontinuous analogic system. Does intermediality still make sense in the era of post-media? And, in particular, how do digital natives, with their specific cognitive abilities perceive intermediality, if they do? Can we think of literature in terms of a fluid intermedial relation of writing to other media? And does such an approach help when it comes to teaching literature to digital natives who participate, since birth, in a digital media circuit where different semiotic systems and codes are constantly remediated? What are the intermedial products that the creative industries are designing specifically for them and what is the educational value of such products? Taking Shakespeare as an eminent example of a writer whose work has been adapted to all kinds of media, this article focuses on the phenomenon of British theatre productions that are conceived to be screened live in cinemas all over the world and presents the results of a pilot experiment devised to investigate the reception of one of these productions by a sample audience of Italian teenagers.

\section{INTERMEDIALITY AND THE DIGITAL TURN}

If the interest in the wide and heterogeneous field of intermediality is evidence today of "a heightened awareness of the materiality and mediality of artistic practices and of cultural practices in general," as the German scholar Irina Rajewsky remarks, it is true that interarts studies have always shown such awareness, and to be fair "what 
is generally treated under the heading of intermediality is in no way a novelty." What is utterly new, however, is the nature of new media and the extraordinary impact that digital technology has had on communication practices, including those specifically considered as artistic or cultural. We are today compelled to acknowledge that the privileged relation, which had traditionally linked specific semiotic systems to specific media, technologies, and institutional channels, has been weakened to the point of breaking loose. This is the crux of the contemporary debate on media.

What the digital turn has radically questioned, according to some critics like Friederich Kittler, is precisely the distinction between media; due to the switch from analogue to digital, heterogeneous semiotic systems have been translated into the same language of bits. A message can now move freely and smoothly in a media circuit made of integrated and interfacing platforms, without suffering any of the discontinuities that characterized the system of analogue media. In rather apocalyptic terms Kittler announces that:

The general digitalization of information and channels erases the difference between individual media. Sound and image, voice and text have become mere effects on the surface, or, to put it better, interface for the consumer [...]. In computers everything becomes number: imageless, soundless, and wordless quantity. And if the optical fiber network reduces all formerly separate data flows to one standardized digital series of numbers, any medium can be translated into another. Modulation, transformation, synchronization; delay, memory, transposition; scrambling, scanning, mapping - a total connection of all media on a digital base erases the notion of the medium itself. ${ }^{2}$

I Irina Rajewsky, "Intermediality, Intertextuality, and Remediation: A Literary Perspective on Intermediality," Intermédiality: History and Theory of the Arts, Literature and Technologies, no.6 "Remédier/Remediation," 2005, p. 44. For a critical debate on intermediality and new media, see also two theoretically challenging new collections: Lars Elleström(ed.), Media Borders, Multimodality and Intermediality, New York, Palgrave Macmillan, 2oro; and Jørgen Bruhn, Anne Gjelsvik, and Eirik Frisvold Hanssen (eds.), Adaptation Studies: New Challenges, New Directions, London, New York, Bloomsbury, 2013.

${ }^{2}$ Friedrich Kittler, Literature, Media, Information Systems, Amsterdam, OPA, 1997, p. $3 \mathrm{I}-32$. 
But is it still possible to talk of intermediality if the difference between media is no longer perceivable? Or is digitalization nullifying the difference between media to the point of radically questioning the very notion of intermediality? Irina Rajewsky's answer to the latter question is positive: " $[\mathrm{O}]$ nce a medial difference is no longer given, i.e. is no longer discernible, any discussion about intermedial practices in given medial configurations becomes pointless." 3 However, she cleverly breaks the deadlock by resorting to Jay Bolter and Richard Grusin's seminal concept of "remediation" 4 in order to propose the idea of a "virtual intermediality": "digital media not only remediate earlier media and their respective representational practices, but specific intermedial relationships between these earlier media as well."s She thus utilizes the concept of remediation as "a particular type of intermedial relationship, and consequently a subcategory of intermediality in the broad sense." ${ }^{6}$ Rajewsky's position is very convincing, and yet the question of digitalization and the loss of material difference between media remains one of the most controversial points in the ongoing debate on intermediality.

According to the Italian film theorist Francesco Casetti, for example, we are paradoxically thrown into a condition of post-mediality, which compels us to ask ourselves what it is that gives media their identity today. ${ }^{7}$ Casetti's theoretical proposal-which seems to me partly in line with that of critics like Henry Jenkins who draws a distinction between "media" and "delivery technologies" — is to leave aside the argument that strictly identifies a medium with the material technology that historically characterized its birth, in order to focus instead on the form of experience (sensory, artistic, anthropological) that a specific medium created for its users throughout its history. For example, what remains of cinema-the medium that most of all, according to Casetti, shaped our modern sensibility-in post-mediality

\footnotetext{
${ }^{3}$ Rajewsky, 2005, p. 62-63.

${ }^{4}$ Jay David Bolter and Richard Grusin, Remediation: Understanding New Media, Cambridge, MA, MIT Press, 1999.

${ }^{5}$ Rajewsky, 2005, p. 63.

${ }^{6}$ Ibid., p. 64.

7 Francesco Casetti, "I media nella condizione post-mediale: Francesco Casetti," in Roberto Diodato, Antonio Somaini (eds.), Estetica dei media e della comunicazione, Bologna, il Mulino, 20II, p. 313-28.

${ }^{8}$ Henry Jenkins writes that "old media never die [...]. What dies are simply the tools we use to access media content - the 8-track, the Beta tape. These are what media scholars call delivery technologies. [...] Delivery technologies become obsolete and get replaced; media, on the other hand, evolve." Henry Jenkins, Convergence Culture: Where Old and New Media Collide, New York, New York University Press, 2006, p. I3.
} 
(and I am here oversimplifying a complex theory), is the viewer's experience, which, once separated from the original technology (film reels, projector, silver screen), is relocated in new technological devices (personal computers, smart phones, electronic billboards, etc.) and in new spatial contexts (home, office, squares and roads, airports and train stations, etc.) thus transforming the environment where it is displayed into a diffused visual space. To acknowledge that what remains of cinema is a specific way both of organizing moving images in order to tell stories and looking at the world through screens, is a much more fruitful theoretical attitude than continuing to lament its impending death. If the specific identity of media is conceived as rooted in the experience they historically fashioned, then we can say that media survive beyond the death of their original technology.

I find this theoretical position appealing, because it brings to the fore the centrality of the recipients' mind, the inherited and evolving cognitive capacity of making sense of the flux of mediated and dematerialized information in which we are constantly immersed: we live among (inter) post-media. This is all the more true for the younger generations who participate, from birth, in a digital media circuit where different semiotic systems and codes are constantly remediated, forming new and unexpected combinations. I am thinking of subjects whose categories of apprehension of the world (starting from space and time) have been strongly affected by their being in the "here and now" of the internet world and at the same time in the "there and then" of the recorded reality of digital media. Famously, Marc Prensky - a writer and game designer in the field of education - coined a term in $200 \mathrm{I}$ to define the natural-born users of digital technologies who, according to him, were developing different "thinking patterns"; he used a metaphor related to language learning, and called them "digital natives," thus also labelling the rest of the world's population as "digital immigrants":

Our students today are all "native speakers" of the digital language of computers, video games and the Internet. So what does that make the rest of us? Those of us who were not born into the digital world but have, at some later point in our lives, become fascinated by and adopted many or most aspects of the new technology are, and always will be compared to them, Digital Immigrants. [...] Digital Immigrants [...] always retain, to some degree, their accent $[\ldots]$ Today's older folk were "socialized" differently from their kids, and are now in the process of learning a new language. And a 
language learned later in life, scientists tell us, goes into a different part of the brain. ${ }^{9}$

Prensky, therefore, not only gave a name to a new group of people, but also singled "us" out, those who came before them, and who are still historically in charge of administering the transfer of knowledge to them via educational institutions (schools and universities). Being a "digital immigrant” myself, born in 1966, and a teacher as well as a researcher in English literature, I feel challenged by the digital divide while I am fascinated by the cognitive processes of the newest generations, which seem to me so different from mine that I need to try and understand them if I want to design effective teaching methods.

How do digital natives experience the forms of virtual intermediality? What are the cultural products that creative industries are specifically inventing for them? And what is the educational potential of these products? Pressed by the need to answer these (and more) questions in a "localized" and direct way, I felt growingly compelled to resort to field experiments (qualitative research oriented), as far as this is possible in the area of the humanities. I started by planning a pilot investigation on a sample of I52 Italian students, aged from is to I7, from three high schools in Rome, the city where I live and teach. I organized for them a matinée in a downtown cinema to see Kenneth Branagh's production of Romeo and Juliet at the London's Garrick Theatre, which was designed to be broadcast worldwide. ${ }^{\text {Io }}$ In the last part of this

9 Marc Prensky, “Digital Natives, Digital Immigrants, Part I," On the Horizon, vol. 9, no. 5, 20oI, p. I-2. From that pioneering article a number of studies have been published on the topic, but I would like to mention, in particular, one of the latest: Alexiei Dingli and Dylan Seychell, The New Digital Natives: Cutting the Chord, Berlin, Springer Verlag, 2015. Dingli and Sychell focus on what they call $2 \mathrm{DN}$ (the second generation Digital Natives), that is, those who were born when the wireless and mobile technologies had already been invented (p. 20-22).

1o The intermedial phenomenon of "live" theatre on cinema screens is rapidly expanding, and it brings with it many crucial issues. Firstly, what is it that we should consider "live" today and what not? This is a big question that deserves to be analyzed closely and in depth, therefore I will not even touch upon it here. Claire Read's reading of the transformation of the concept of "live performance" in the digital age through the work of Philip Auslander, applied to the NT Live production of The House, is of particular interest. She writes: "[B]ecause liveness has been disrupted by mediatization [...] a confusion concerning the definition of liveness has evolved as events that offered co-temporal and co-spatial liveness were labelled as live, in addition to performances that could not offer both co-temporal and co-spatial liveness but offered instead one element of liveness or an overall 'sense' of liveness. Questioning his previous definition of liveness, Auslander promotes instead a digital liveness, exemplified by 
paper I will present a few observations on some of the answers that the sample audience of students gave to the short questionnaire I asked them to fill in after the show. But before getting there, I would like to reflect on a few ideas about literature, writing, and the media system in order to share my own understanding and use of the term "literary intermediality."

\section{LITERARY INTERMEDIALITY}

As a teacher and researcher in the field of literature my perspective on intermediality has always been literary-oriented, ever since the first seminar I convened on the topic, in 2004 (at the 7 th ESSE Conference-Zaragoza), with the title "Intermediality and Literary Practices." II I had started to teach English literature classes at Roma Tre University in 2002 and I was haunted by one of the most widespread and dismayed observation circulating at the time among teachers: "Our students do not distinguish between a novel and the film inspired by it." Was that true, I used to ask myself. And if so, why? I therefore started to investigate the phenomenon of film adaptation as the transfer of literature from page to screen in an intermedial perspective (a crossing of media boundaries). While students seemed to appreciate a practical approach to literature via adaptation, my research concern began to focus on what remains of literature in screen adaptations of literary texts; this led me to consider how a literary message could be defined, and thus, finally, back to the almost unanswerable question: What is literature? While I was sinking into theoretical quicksand, Terry Eagleton came to my rescue with his provocative definition of literature as "a functional rather than an ontological term." ${ }^{2}$ According

the mediatized re-presentations of performance, such as those offered from live streaming. Enabling a terming of those performances not previously considered 'live' as digitally 'live,' Auslander's reconsideration of the value of liveness affectively alters the nature of (digital) performance and its documentation, as documentation becomes referentially 'live,' akin with the nature of performance.” Claire Read, “'Live or almost live...' the Politics of Performance and Documentation," International Journal of Performance Arts and Digital Media, vol. Io, no. I, 20I4, p. 68.

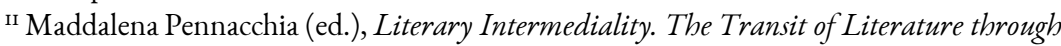
the Media Circuit, Bern, New York, Peter Lang, 2007, and "Intermedialità letteraria. Note sul nomadismo mediatico della letteratura," in Lucia Perrone Capano (ed.), Il testo oltre i confini. Passaggi, scambi, migrazioni, Bari, Palomar, 2009, p. 357-375.

${ }_{12}$ Terry Eagleton, Literary Theory. An Introduction, London, Blackwell, 1983, p. 8, italics in original. 
to the English materialist critic, literature depends on "how somebody decides to read, not [on] the nature of what is written," ${ }^{13}$ or, to put it differently, we may think of literature "as a number of ways in which people relate themselves to writing." ${ }^{4}$ Starting from this illuminating suggestion, I went back to the dictionary where I was reminded of the etymology of the word "literature," whose root, not only in English but in most European languages, is to be found in the Latin word littera, a letter (of the alphabet), that is, a single written sign that stands for a sound; it is the same root of "literacy," which means being capable to write and read. I therefore thought that if literature is culturally and historically linked to phonetic writing (and therefore to reading), I could venture to say, with Eagleton at my side, that a literary message, at least in the Western tradition, has to do with its written form, whatever the imaginative/narrative content it conveys and the institutional and material channel through which it is transmitted.

Indeed, phonetic writing is, according to many anthropologists, historians, and philosophers, the most extraordinary of human inventions: born in Greece and spread by the Latin culture, it became one of the most powerful technologies through which humans have been able to store a potentially infinite amount of information, thus objectifying ideas that could be disseminated, like goods, in space and time. If much was gained, however, something was lost in the process, because, as Marshall McLuhan remarked in Understanding Media, in the phonetic alphabet-where "semantically meaningless letters are used to correspond to semantically meaningless sounds" is —a "sudden breach between the auditory and the visual experience of man"16 opened, because the alphabet gave its user "an eye for an ear." ${ }^{\text {"17 }}$ McLuhan's pupil Derrick de Kerckhove started from there (and from the work of Eric A. Havelock) to develop his own fascinating "neurocultural research" aimed at checking the impact of media on the nervous system within a cognitive and emotional framework:

when the Greeks introduced vowels to adapt the Phoenician alphabet to suit the needs of their own Indo-European language, they changed the nature of

\footnotetext{
${ }^{13}$ Ibid., p. 7 .

${ }^{14}$ Ibid., p. 8, italics in original.

is Marshall McLuhan, Understanding Media. The Extensions of Man [1964], Cambridge, MA, London, MIT Press, 1994, p. 83.

${ }^{16}$ Ibid., p. 84.

${ }^{17}$ Ibid.
} 
the reading process from a context-based to a sequence-based decipherment. This change in turn may have been responsible for the reorganization of brain strategies, and this may explain why the direction of writing changed from the leftward orientation of Phoenician to rightward. The implications of such a change may have had far reaching consequences on the biases of Western cognition. ${ }^{18}$

Phonetic writing, if we accept these theoretical stances, is what made us what we are now; it literally changed our way of seeing the world through a deep transformation of the neurophysiology of the brain, thus turning the human being, at least in Western culture, into what de Kerckhove also calls homme littéré (man of letters), a misspelling of homme lettré (literate man). ${ }^{19}$ The bomme littéré is an individual-a unique being, distinguished from the community-capable not only of gaining an unprecedented control over language, but of relating and knowing the world through an extremely refined conceptual system of left-to-right-oriented sequences of letters, which made the world itself symbolically available for further complex abstract operations. McLuhan had already remarked that writing is to be considered a medium, an extension, as it were, of the human vocal tract: " $[T]$ he content of writing is speech, just as the written word is the content of print, and print is the content of the telegraph." ${ }_{20}$ If we accept seeing it as a sort of $u r$-medium, we can also see how phonetic writing has always related itself to the other media in the communication system or, to use Bolter and Grusin's critical jargon, writing has been repeatedly remediated in all the media that came after it: the telegraph, the radio, cinema, television, the computer, and, now, the internet.

Considering all this, I gradually shifted the focus of my research from an initial idea of a possible linear migration of literature from page to screen towards the idea of a more radical nomadism of writing within the media circuit. As for my initial question about what remains of literature in film adaptation, I became growingly

${ }^{18}$ Derrick de Kerckhove, "Critical Brain Processes Involved in Deciphering the Greek Alphabet," in Derrick de Kerckhove and Charles J. Lumsden (eds.), The Alphabet and the Brain. The Lateralization of Writing, Berlin, Heidelberg, Springer Verlag, 1988, p. 40I.

I9 See Derrick de Kerckhove, L'uomo 'letterizzato,' in Gianluca Bocchi and Mauro Ceruti (eds.), Origini della scrittura. Genealogie di un'invenzione, Milano, Mondadori, 2002, p. 268-8o.

${ }^{20}$ McLuhan, 1994, p. 8. 
interested in the script as a practice of rewriting and resorted to Pier Paolo Pasolini's brilliant theory of the screenplay as a "structure that wants to be another structure" in order to define the script as a form of intermedial writing that is suspended between page and screen, the book and the film. ${ }^{22}$

To think of literature in terms of an intermedial relation of writing to other media broadened my perspective and helped me to approach the many different literary phenomena of the digital age with a higher awareness that there is more to literature than what we have been taught to think about. Literature is not dying just because the printed book - for a long time its privileged vehicle-has lost its superior position in the hierarchal system of analogic media. Digitalization did not spell the death of literature, but it swallowed the printed book up into its heterarchical media system: the book is, today, only one of the stages in the circulation of literary contents or, to put it differently, writing (and its related activity, reading) is disseminated throughout an interconnected system of digital media. Writing is everywhere, even when we do not see it; it presides not only over our operations of coding and decoding the world, but in post-literate societies it still is the necessary basis, made of invisible scripts, of that "return of the sound" (in radio, cinema, television, and the internet), which Walter Ong famously called "secondary orality." ${ }^{23}$

Such an understanding of literary intermediality gradually strengthened through the study of Shakespeare, whom I came to see as an eminently intermedial writer. ${ }^{24}$ And to Shakespeare we now turn.

\section{Theatre-Cinema Shakespeare for Digital Natives: the CASE OF BRANAGH'S ROMEO AND JULIET ON ITALIAN SCREENS}

Shakespeare's macrotext, and the many uses it has been put for centuries, is one of the most fascinating and productive fields of research when the theory of literary intermediality is concerned. It is no chance that McLuhan nourished a

\footnotetext{
${ }^{21}$ Pier Paolo Pasolini, "La sceneggiatura come 'struttura che vuol essere altra struttura'," in Empirismo eretico, Milano, Garzanti, 1972, p. I88-197.

${ }^{22}$ See Maddalena Pennacchia, "Letteratura e intermedialità: l'adattamento filmico," in Silvia Bigliazzi and Gregori Flavio (eds.), Critica e letteratura. Studi di Anglistica, Pisa, ETS, 2015, p. I2I-I39.

23 Walter J. Ong, Orality and Literacy [1982], London, New York, Routledge, 2002.

${ }^{24}$ Maddalena Pennacchia, Shakespeare intermediale. I drammi romani, Spoleto, Editoria $\&$ Spettacolo, 2012 .
} 
lifelong interest in Shakespeare, a figure who presides over the most important phases of his rethinking of the history and theory of media. Richard Cavell has recently traced McLuhan's references to the Bard and his time since McLuhan's completion of his $\mathrm{PhD}$ dissertation on the Elizabethan playwright Thomas Nashe, a piece of work that he wrote at Cambridge, beginning in 1939, under the supervision of Muriel Bradbrook. There he argued, as Cavell reports, that "it was the hybrid interface of oral modalities with scribal media in the Elizabethan era that produced the complexity of its literature.”25

As it happens, Shakespeare did not care to edit his plays, a historical fact whose importance cannot be overlooked. Born in the period of early print culture, when there was a stronger residual orality, Shakespeare's writing is radically suspended between play-text and performance. David Scott Kastan rightly remarks in Shakespeare and the Book:

[n] ot only theoretically, but also historically, the text of Shakespeare's plays can claim, not precedence over performance, but parity with it. Although Shakespeare did indeed write his plays to be performed, they quickly escaped his control, surfacing as books to be read and allowing Shakespeare to "live" no less vitally in print than he does in the theatre. ${ }^{26}$

For Shakespeare, in other words, the relation between the play-text and its performance is not simply that of origin and effect (in whatever order one might conceive it).

There is no way out of the paradox of Shakespeare's writing. When seen from our current position in history, that paradox looks like a warning engrafted right at the core of the nascent Gutenberg age, as a prophecy of the epistemic break that was to be brought about by the digital turn, centuries later, when print ceased to be the privileged medium for the transmission of "literary" contents. The fluid writing that floods our digital culture helps us to better understand the materiality of Shakespeare's writing, but also forces us to remember the historicity of "Literature"

${ }^{25}$ Richard Cavell, "Mediatic Shakespeare: McLuhan and the Bard,” in Irene R. Makaryk and Kathryn Prince (eds.), Shakespeare and Canada: Remembrance of Ourselves, Ottawa, University of Ottawa Press, 2017, p. 158.

${ }^{26}$ David Scott Kastan, Shakespeare and the Book, Cambridge, UK, Cambridge University Press, 20oI, p. 9. 
as a discursive formation (in the Foucauldian sense) that established its legitimacy upon the creation of the notion of the Author and the book as the only authorized vehicle of his/her written messages. ${ }^{27}$

Starting from this premise, we may argue that, as a literary message, Shakespeare's text is "ontologically" intermedial because, from birth, it wavers between page and stage, between the differing media of the printed book and the theatre: ${ }^{28}$ it is, accordingly, in the crossing of media boundaries that it takes on its shape, or better, its many shapes, not only in the printed book and in the theatre, but also, as witnessed by the history of Shakespeare in the media, the radio, cinema, television, and the internet. By materializing into different products that are fashioned by different media, Shakespeare's writing acquires meaning through the difference between them; it is therefore not only unstable, ${ }^{29}$ but does seem to possess an intermedial predisposition and, consequently, an unusual aptitude for adaptation that has always enabled it to cross arts and media boundaries with ease.

The adaptability of Shakespeare's writing goes hand in hand with its growing value as cultural capital, one that is capable of satisfying both lowbrow and highbrow cultures and of pleasing and interesting users of any gender and age, from distant geographies and varied socioeconomic conditions. The latest intermedial products

${ }^{27}$ This and the following paragraph summarize my particular contention in Shakespeare intermediale, Pennacchia, 20I2, p. I3-5I.

${ }^{28} \mathrm{I}$ am aware that it is contentious that theatre might be considered a medium, and for a stimulating perspective on this, see Fabrizio Deriu, "Il teatro è un medium? Questioni e risposte in prospettiva 'mediologica," Mantichora, no. 5, 2015, p.59-65, http://ww2.unime.it/mantichora/wp-content/uploads/2016/o6/Il-teatro-\%C3\%A8-unmedium.-Questioni-e-risposte-in-prospettiva-mediologica.pdf (accessed 20 July 20I7). As I see it, however, theatre has specific communicative technologies, semiotics, and institutional loci where actors and the audience meet, to which it must be added that theatre (ontologically speaking) always re-presents human experience as mediated. Considering a further aspect of the mediality of theatre, I also tend to agree with Chiel Kattenbelt's idea of theatre as "hypermedium," that is to say, theatre not only relates to all media (and to their specific representational practices and semiotic systems), but it is capable of showing them in performance thus avoiding their refashioning into a different mediality while transforming them instead into theatrical signs. Theatre, thus intended, becomes a "stage of intermediality"; see Chiel Kattenbelt, "Theatre as the Art of the Performer and the Stage of Intermediality," in Freda Chapple and Chiel Kattenbelt (eds.), Intermediality in Theatre and Performance, Amsterdam, New York, Rodopi, 2006, p. 29-39.

29 See Ernst A. J. Honigmann, The Stability of Shakespeare's Text, London, Edward Arnold, 1965 . 
invented by the creative industries to turn a profit with such a capital are stage productions of Shakespeare's plays put on in prestigious theatres in the UK, filmed, and broadcast live-or "almost live" 30 - on cinema screens in the UK and all around the world. I would like to call this kind of aesthetic objects "theatre-cinema," with a hyphen, that is, cultural products whose main characteristic is precisely their being situated between different media and semiotic codes, which are in a significant and evident relation to each other, not belonging to one in particular but participating in each; ${ }^{3 \mathrm{I}}$ theatre-cinema productions are not, of course, limited to Shakespeare, even though the Bard infallibly hits the mark.

When the project of the National Theatre Live (NT Live) launched in June 2009, the opening broadcast was Racine's Phèdre with Helen Mirren; since then, as we read on the NT Live's website, it has broadcast "more than forty other productions live, from both the National Theatre and from other theatres in the UK." ${ }^{22}$ The most successful of all NT Live broadcasts to date, however, has been Lindsay Turner's Hamlet, at the Barbican Theatre, with celebrity actor Benedict Cumberbatch (a I2-week-run production, from August to October 2015), a show that was seen on screen "by over 550,000 people." ${ }_{33}$ As Boika Sokolova and Nicoleta Cinpoes have remarked, pointing to the paradoxical character of this hybrid aesthetic object, Turner's production employed cinematic special effects that made it particularly palatable to cinema spectators, but were lost to theatre audiences. 34 Nevertheless, even though the prioritization of cinema over theatre in this production may give rise to controversial reactions, it was precisely the stylistic marker that strongly contributed to its success all over the world. Larger than usual "audiences who are lapsed theatre goers" 35 were engaged and their passion for more

$3^{30}$ I am borrowing the expression used by Claire Read in her already quoted article: Read, 2014.

${ }^{31} \mathrm{My}$ use of the hyphen follows the logic of the neologism "image-text" invented by W. J. T. Mitchell in contrast to "image/text" and "imagetext." He used "image-text" to point specifically to the "the relationship of visual and verbal" (my italics). W. J. T. Mitchell, Picture Theory. Chicago, University of Chicago Press, 1994, p. 89 (footnote 9).

${ }_{32}$ "Who We Are and What We Do," NT Live, http://ntlive.nationaltheatre.org.uk/about-us (accessed I2 July 20I7)

33 Ibid.

34 Boika Sokolova and Nicoleta Cinpoes, "The 'Cumberbatch' Hamlet (I): 'The very age and body of the time his form and pressure'," Cabiers Élisabéthains, vol. 93, no. I, 20I7, p. 124132.

35 George Jarrett, "The Latest in Live,” TVB Europe, January 2or6, p. 30. 
traditional theatre productions may have been rekindled; this at least was the hope of Emma Keith, NT Live producer, who also explained in an interview that in September 2016 NT On Demand was launched in secondary schools: "[A] three-year pilot started with our productions of Hamlet, Othello and Frankenstein" ${ }^{6} 6$ to which one thousand schools signed up. The educational aim of the project is, clearly, strong as is its interest in the development of young audiences. Though laudable, we may be tempted to ask whether theatre-cinema products will not inevitably spoil the expectations of potential young theatre-goers who, once in an actual theatre, may find out (perhaps with frustration) that you cannot always be in visual control of the performance-not even from the best seat in the house.

In Italy the broadcast of Hamlet was managed in the 2015-2016 season (19-20 April 2016) by Nexo Digital, a pioneer company "committed to distributing quality events of cultural and social value and promoting a new way of living the cinema experience." 37 In the interview I held with the cultural project manager of the company, Luana Solla, she stated that Hamlet was their biggest broadcast ever, with 28 ,00o people attending in the first two days. ${ }^{8}$ This may have been due to the promotion of the event within the international programme Shakespeare Lives, which was organized by the British Council on the occasion of Shakespeare's 4ooth anniversary and in partnership with GREAT Britain, UK Trade and Investment, and Visit Britain. More interestingly, however, Solla added that for the first time a new marketing strategy had been used with advertisements for the event posted on the social media sites of Cumberbatch's fan clubs. From the feedback they received via email and by monitoring social media in the days soon after the broadcast, the company inferred that the audiences were unusually young, perhaps due to the leading actor's celebrity status among teens (he was famous at the time for his leading role in the Sherlock TV series and his participation in such films as Star Trek-Into the Darkness). Be that as it may, the educational commitment of the Italian company is as strong as that of NT Live and they have a very efficient school-dedicated staff in the marketing department through which the company contacts schools and organizes special events at a convenient price. Encouraged by the extraordinary fortune of Hamlet, Nexo Digital distributed more Shakespeare in the following season, 2016-20I7, this time in partnership with the Branagh Theatre Live Company,

\footnotetext{
${ }^{36} \mathrm{Ibid}$, p. 29.

37 See the website of the company: http://www.nexodigitalcinema.com/chi-siamo/ (accessed 7 January 20I8).

${ }^{38}$ Interview by email with Luana Solla, 24 July 2016.
} 
which produced and staged at the Garrick Theatre The Winter's Tale, starring Branagh and Judi Dench, and Romeo and Juliet with Derek Jacobi, Lily James, and Richard Madden; Rupert Goold's Richard III starring Ralph Fiennes and Vanessa Redgrave performed at the Almeida Theatre was also included. The Nexo Digital programme was nicely packaged as the "Great English Theatre at the Cinema" ("Il grande teatro inglese al cinema") and had the endorsement of the British Council.

With the organizational support of Nexo Digital Italy, the Farnese Cinema $\mathrm{Lab}$ (Rome), and a group of teachers from three high schools in downtown Rome, I arranged a matinée on the 30 November 2016 to which Italian students aged between I5 and 17 were invited to see Kenneth Branagh's production of Romeo and Juliet. I chose this particular production because it is the Shakespeare play teenagers would have at least heard of. Moreover, Branagh purposefully employed two darlings of young audiences in the title roles, Lily James and Richard Madden, whom he had already directed in Walt Disney's live action remake of Cinderella (2015). I therefore created a questionnaire that was distributed to the 152 students who participated in the viewing; they completed it in their classrooms under the supervision of their teachers in the first week after the event. 39

Kenneth Branagh's production of Romeo and Juliet (which ran from I2 May to 13 August 2016) was well (but not enthusiastically) reviewed by both press and audiences, with Michael Billington highlitghting the overall visual approach to the play:

There are many ways of approaching Shakespeare's youthful tragedy: Rob Ashford and Kenneth Branagh take the scenic route in this new production. We are plunged into a vividly imagined I950s Italy of dark-suited men, petticoated women, bicycling friars, patriarchal oppression and frantic partying. You feel Fellini is due any moment to film it with a movie camera and, even if the result has its oddities, the production certainly has a pulsating energy. ${ }^{40}$

39 I am grateful to Fabio Amadei (Farnese Cinema Lab-Europa Cinemas Network) and the teachers of Liceo Mamiani (Bianca Mazzola, Antonella Santambrogio, Giuseppe Stinca), Liceo Virgilio (Maria Teresa Tosetto, Lucia Cardarelli, Grazia Maria Bertini and Laura Marocco) and Scuola Pontificia Pio IX (Eugenia Campini and Elisabetta Diadori) who offered their support for this activity.

${ }^{40}$ Michael Billington, "Romeo and Juliet Review_Branagh Gives Tragedy a Touch of la dolce vita," The Guardian, 26 May 2016, https://www.theguardian.com/stage/2016/may/26/romeo-and-juliet-review-branagh-lilyjames-richard-madden-garrick-theatre (accessed 7 January 2018). 
The mention of Fellini is a key to the aesthetic choices made by producers for this hybrid product which, being destined from birth to be broadcast on screens, made much of intermedial references to cinema; in fact, it openly pays homage to the seventh art not only on stage, but even more so on screen, where it was presented in high definition black and white.

Interestingly, the most articulated explanations about the artistic approach are to be found online in the words spoken by Lily James probably at the press release conference, a speech which sounds, perhaps also for marketing reasons, specifically addressed to young people:

The live broadcast is so exciting because it gets the play out of the Garrick Theatre and across the world, opening it up to an entirely different audience. It's great to get a younger audience in too, with the cheap tickets available for students. My brother will be watching in Australia! When Ken first talked to me about Romeo and Juliet he described how we would really try and capture the thriller aspect of the story and set it in I950s Italy, firmly in the world of la dolce vita. The feel would be monochromatic, like those beautiful old black and white movies of that time, and it all immediately felt very filmic anyway. Howard Hudson has done such a brilliant job with the lighting and Christopher Oram's set is so atmospheric and realistic, so hopefully the play will translate well to the cinema. I really think it's so exciting to see Shakespeare on film and to watch plays displaced from their original setting into a new medium. I can't wait!4I

As is well known, this kind of production always engages a stage director (Kenneth Branagh) and a film director (Benjamin Caron). Branagh, who is celebrated for his film directorial style seems to have adapted it for the stage: musical numbers are made the most of, as when Romeo first notices Juliet at the party because she takes centre stage under a spotlight by singing a jazz song for her father (she cannot go unnoticed); comedy is brought to the fore every time this is possible, as in the balcony scene, when Juliet looks inebriated and the whole renowned dialogue takes on a slapstick flavour;

\footnotetext{
${ }^{41}$ Quoted, among others, in Andrew Gans, "Kenneth Branagh—Rob Ashford Directed Romeo and Juliet to Hit US Cinemas," Playbill, 25July 2016, http://www.playbill.com/article/kenneth-branagh-rob-ashford-directed-romeo-and-julietwill-hit-us-cinemas-in-august (accessed 7 January 2or8).
} 
there are visually captivating expedients, like the circular white tulle tent under which Juliet drinks Friar Lawrence's potion and to which she clings, spinning, and tearing it down, thus looking as if wrapped in her bridal veil or death shroud; the pace is fast when not hasty and there is a general tendency towards visual symmetry. On his side, Caron avoids any of the typical Branagh filming techniques and makes instead a moderate use of close-ups and whirling camera movement, preferring medium and wide shots that can convey the sense of what is happening on the entire stage.

I opened the matinée with a brief introductory warm-up dialogue during which I found out, by a show of hands, that most of the students had seen Cinderella and knew who the leading actors were (boys and girls equally thrilled), while they were utterly unaware of who Kenneth Branagh was, and totally uninterested. We immediately started the viewing, which it was very important to me to share with them as an "immersed" observer. For instance, I was struck by the audible gasp the audience let out when Juliet wakes from her sleep within seconds of Romeo's death. At that moment, no matter how many of the students already knew the story, a frisson spread contagiously-a bodily phenomenon that usually happens when people are together in the same (representational) space, and that might even have to do with our mirror neurons. ${ }^{42}$ The involvement in the scene was palpable.

In the questionnaire I gave the students I began by asking how often they go to the theatre and how often to the cinema. Their answers are presented in Tables I and 2 below.

${ }^{42}$ The existence of mirror neurons in the brain of human beings and primates as well as their role in the phenomenon of empathy is controversial. However, I would like to hint at this field of research by quoting extensively from an essay by the Italian neuroscientists Pier Francesco Ferrari and Vittorio Gallese from the University of Parma, who "propose that the mirror neurons and mirror-related mechanisms [...] may represent the neurobiological grounding for the expression of some forms of primary and secondary intersubjectivity. These mechanisms allow individuals to participate in another's action, feeling or emotion through preferential access of the visual information about the outside social world to our sensorimotor experience. [...] With this mechanism we do not just 'see' an action, an emotion, or a sensation [...] Our brains, and those of other primates, appear to have developed a basic functional mechanism, embodied simulation, which gives us an experiential insight of other minds," Pier Francesco Ferrari and Vittorio Gallese, "Mirror Neurons and Intersubjectivity," in Stein Braten (ed.), On Being Moved. From Mirror Neurons to Empathy, Amsterdam, Philadelphia, John Benjamins Publishing Company, 2007, p. 85. 


\section{Table I}

\begin{tabular}{|l|c|c|}
\hline How often do you go to the theatre? & Female & Male \\
\hline Never & $7.7 \%$ & $24.1 \%$ \\
\hline At least once a year & $55.5 \%$ & $58 \%$ \\
\hline Once a month & $35.5 \%$ & $17.7 \%$ \\
\hline Once a week & - & - \\
\hline No answer & $1.1 \%$ & - \\
\hline
\end{tabular}

\section{Table 2}

\begin{tabular}{|l|c|c|}
\hline How often do you go to the cinema? & Female & Male \\
\hline Never & $1.1 \%$ & $3.22 \%$ \\
\hline At least once a year & $7.7 \%$ & $11.2 \%$ \\
\hline Once a month & $70 \%$ & $69.3 \%$ \\
\hline Once a week & $21.1 \%$ & $16.1 \%$ \\
\hline
\end{tabular}

As may be inferred from the figures, cinema is still the "mass medium" young people attend most frequently (once a month for almost 70\% of them, both girls and boys); the outcome I did not expect, however, is that more than $50 \%$ of them go to the theatre on an annual basis. This could be related, however, to the fact that in their high schools, in Rome, a capital city, there are educational projects aimed at developing audiences and making the theatre known to young people. Be that as it may, they were equipped to tell the difference between a traditional live performance in the theatre and a traditional film on screen. This confirms that the efforts towards audience development and awareness can be very effective and should be further pursued. ${ }^{43}$ In fact, the students' answers to the following question (see Table 3 ) bear witness to their appreciation of the experience in terms of media specificity.

${ }^{43}$ The cinema where I organized the matinée is part of the Europa Cinemas Network, a project launched in 1992 with funding from Creative Europe (MEDIA programme) and from the Centre national du cinéma et de l'image animée(CNC): https://www.europacinemas.org/en/Presentation (accessed 26 March 2018). Particularly important in terms of audience development and empowerment was also the programme European Audiences 2020 and beyond, which was launched by the European Commission: http://www.kulturradet.se/Documents/Kulturkontakt/EU/20I4/European\%20Audiences \%202020\%20and\%2obeyond.pdf (accessed 26 March 2018). 
Table 3.

\begin{tabular}{|l|c|c|}
\hline What you have experienced is: & Female & Male \\
\hline theatre more than cinema & $44.4 \%$ & $48.3 \%$ \\
\hline cinema more than theatre & $18.8 \%$ & $24.1 \%$ \\
\hline cinema and theatre equally & $33.3 \%$ & $27.4 \%$ \\
\hline No answer & $3.3 \%$ & - \\
\hline
\end{tabular}

Only a very small percentage of students perceived the experience they had to be "cinema more than theatre" (I8.8\% female and 24.I\% male). Most of them found that it was "theatre more than cinema" or, at least, "cinema and theatre equally." The audience was able to perceive what, with Rajewski, we have called "virtual intermediality," and this seems to point to a correct response to the educational design inscribed in most of the theatre-cinema products. For example, they often feature an introduction that shows the theatre venue in detail, telling a little bit of its story, and often trying to relate the show with the actual life of young theatre-goers interviewed on the spot. The cinema audience is clearly made aware that they are viewing a filmed performance (during the intermission, the cameras even show the audience in the theatre). In this case the beautiful visual presentation of the historical Garrick Theatre was accompanied by Branagh's voice off narrating an anecdote of Oscar Wilde's life that moved him to cast Derek Jacobi as Mercutio, a "daring” directorial choice, since Romeo's friend should be his age, while in this production he is an aging dandy who likes the company of young people.

Quite predictably, a very high percentage of the students (more than $70 \%$, see Table 4) had already seen Romeo and Juliet.

\section{Table 4.}

\begin{tabular}{|l|c|c|c|}
\hline $\begin{array}{l}\text { Had you already seen Romeo and } \\
\text { Juliet? }\end{array}$ & Female & Male \\
\hline No & $24.4 \%$ & $29 \%$ \\
\hline Yes & $74.4 \%$ & $70.9 \%$ \\
\hline No answer & $1.1 \%$ & - \\
\hline
\end{tabular}

But when asked in what medium (theatre, cinema, television, or the internet), "television" was the most chosen answer (more than 60\%), while I would have expected the internet (only about $15 \%$ ). As I said, their emotional participation in the 
story-line was not affected by their knowledge of the story itself, as the episode of the “gasp” makes clear.

The language issue is a big one with respect to this kind of products. In this case, a group of Italian students had to relate to a production delivered in Elizabethan English, screened with Italian subtitles. Branagh's choice to have the actors intersperse their lines with a few Italian (swear)words-a move that was much criticized at home-was enjoyed by Italian students, who felt somewhat empowered by their understanding of Italian dirty jokes. All the same, they had to cope with a very difficult oral and written text in two different languages.

Subtitles are not a choice to be taken for granted in Italy, for the traditional and more widely-used kind of audiovisual translation in our country is dubbing, a practice that tends to erase linguistic difference by radically domesticating, as it were, the foreign audiovisual product and giving it a new local voice. ${ }^{44}$ In theatre-cinema events, on the contrary, the trend is to use subtitles. In my interview with Luana Solla I asked whether Nexo Digital Italy had taken care of the subtitles for Hamlet (I wanted to know if the translator had checked any published Italian translation of the play), but she told me that the translations were done directly by NT Live, which offered a global product that had already been customized with the right subtitles for each non-English speaking country. Possibly this happened with Romeo and Juliet too.

My question for the students, therefore, was "Did you find that subtitles were helpful in the understanding of the story?” From the answers (see Table 5 ) it is clear that most of the students found subtitles helpful enough or very much so in the understanding of the story.

\section{Table 5.}

\begin{tabular}{|l|l|l|}
\hline $\begin{array}{l}\text { Did you find that subtitles were helpful } \\
\text { in the understanding of the story? }\end{array}$ & Female & Male \\
\hline Not at all & $7.7 \%$ & $8 \%$ \\
\hline Enough & $53.3 \%$ & $37 \%$ \\
\hline Quite & $30 \%$ & $33.8 \%$ \\
\hline Very much & $7.7 \%$ & $20.9 \%$ \\
\hline No answer & $1.7 \%$ & - \\
\hline
\end{tabular}

${ }^{44}$ See Irene Ranzato, Translating Culture Specific References on Television. The Case of Dubbing, New York, London, Routledge, 2016, where the author specifically focuses on the Italian cultural context and history of audiovisual translation. 
Table 6.

\begin{tabular}{|l|l|c|}
\hline $\begin{array}{l}\text { Did subtitles distract you from the } \\
\text { images? }\end{array}$ & Female & Male \\
\hline Not at all & $41.1 \%$ & $40.3 \%$ \\
\hline A little & $54.4 \%$ & $53.2 \%$ \\
\hline Quite & $2.2 \%$ & $4.8 \%$ \\
\hline Very much & $1.1 \%$ & $1.6 \%$ \\
\hline No answer & $1.1 \%$ & - \\
\hline
\end{tabular}

However, what is more interesting is their answer to the next question, "Did subtitles distract you from the images?" This is not an idle question in the context of Italian cinema, both in mainstream and art house productions. Even an intellectual of the calibre of Pier Paolo Pasolini preferred dubbing to subtitles because the latter, he remarked, disrupted the enjoyment of the image, which is everything in cinema. ${ }^{45}$ Quite surprisingly, instead, a very high percentage of students (more than $40 \%$ for both boys and girls, see Table 6) claimed that subtitles did "not" distract them "at all" from the images on screen and more than $50 \%$ of the students declared that subtitles distracted them only "a little." This means that Italian digital natives have no problems accepting that writing and moving images should share the same space on screen. This is, indeed, a significant change for Italian audiences in terms of the new generations' specific skills and habits. Perhaps they are more used than their parents to subtitles because they often watch their favourite American TV series on the internet in the fan-subtitled versions, that is, before they are dubbed into Italian. But there is more to that. I surmise that the ease with which Italian teenagers read subtitles also has to do with their incessant message-sending activity on their mobile phones: they are self-trained in speed reading (and writing) on screen.

Moreover, if in the theatre the written text disappears in order to resurface in the spoken language of the performance, the presence of subtitles on screen in theatre-cinema productions marks the return of writing, and of the script, into the visible space of the performance, thus potentially stimulating the audience's

45 Pier Paolo Pasolini wrote: "Tra i due mali, quello del film non doppiato e con la didascalia in basso sull'inquadratura, e il doppiaggio magari male interpretato (e ricreato) oppure totalmente sciatto, cioè casual, è da preferire il secondo. La didascalia taglia l'inquadratura, e distoglie l'occhio di chi vede e cerca di captare e di capire i rapporti delle immagini tra di loro," quoted in A. Castellano, Il doppiaggio: profilo, storia e analisi di un'arte negata, Roma, AIDAC, 2000 , p. 68. 
awareness of the difference (and productive tension) between play-text (writing), theatre (live performance), and cinema (recording). Teachers might be interested in finding ways to develop such awareness, if they believe it is valuable for their students' cultural and communicative development.

Similarly, subtitles can make the relation between languages perceivable by engaging both the eye (which reads the text that has been translated into Italian while also watching the moving images) and the ear (which listens to the English original performance). If "translation ultimately serves the purpose of expressing the central reciprocal relationship between languages," as Walter Benjamin eminently wrote, ${ }^{46}$ subtitles patently perform just such a task. The young person who participates in a bilingual intermedial experience (as in the case study we have just described) can therefore perceive, almost unwittingly, the difference and the relation not only between media, but also between languages.

It goes without saying that these complex seeing/listening activities can be very demanding for the audience, and yet when asked if they enjoyed the experience, almost all the students participating in the matinée answered that they did (see Table 7).

\section{Table 7.}

\begin{tabular}{|l|c|l|}
\hline Did you enjoy this experience? & Female & Male \\
\hline Not at all & - & $1.6 \%$ \\
\hline Enough & $30 \%$ & $32.2 \%$ \\
\hline Much & $44.4 \%$ & $48.3 \%$ \\
\hline Very much & $24.5 \%$ & $17.7 \%$ \\
\hline
\end{tabular}

Even the rough results of this simple pilot experiment point to the fact that there is still a lot to learn about the perceptive possibilities and watching habits of digital natives, especially with regard to culture-specific experiences such as the Italian one I described. Considering the reception of this theatre-cinema product by the sample of Italian teenagers who participated in the viewing, we might say-as a necessarily tentative conclusion-that intermediality can still make sense for postmedial subjects when they are encouraged to see the difference, albeit virtual, among representational practices that have been historically related to specific media and that

${ }^{46}$ Walter Benjamin, The Task of the Translator, in Hanna Arendt (ed.), Illuminations, New York, Schocken Books, 2007, p. 69-82, p. 72. 
have, consequently, determined different forms of experience, which are part of the cognitive evolution. Such differences often go unrecognized by younger generations, and yet it seems important to preserve the capacity to discern them. The intermedial techniques of theatre-cinema, thanks to devices such as the opening point of view shot by the camera entering the theatre, allow young spectators to grasp the dialectical relationship among media even in a post-medial dimension and enriches their media awareness. The remediation of writing on screen in the form of subtitles, moreover, helps them to see that the recorded performance they are shown is part of a huge reservoir of written stories and ways of telling them that for a long time has been institutionally called Literature.

To think of literature as an historical relationship of writing to other media, can help digital immigrants to better understand contemporary cultural phenomena such as, for instance, transmedial storytelling which is one of the ways digital natives prefer to consume texts, either on the page or, more often, on screens. Conversely, if younger generations are less acquainted with the printed book as a medium, it can be valuable for them to see how writing, once out of the book, runs abundantly throughout the media circuit adapting to new media environments and assuming forms that are compatible with the specific technologies of the different media it crosses, thus releasing its potential to tell imaginative and informative stories.

Therefore, if it is true that digital natives "speak the language" of new media from birth, they do it in a natural way, not knowing its "grammar" and why it works so. Digital immigrants, on the other hand, with their not being completely fluent in that language, may try to put their foreignness to good use, by developing a better awareness of what it means to live in that language and perhaps devise suitable didactic tools to enhance awareness in digital natives too. Finally, it is to be hoped that educators and educational institutions will tailor their programmes to today's students in more effective and specific ways by taking this crucial cultural shift into account, and by devoting more effort to understanding its ramifications. 


\title{
Intermedial Products for Digital Natives: British Theatre- Cinema on Italian Screens
}

\author{
Maddalena Pennacchia, Roma Tre University
}

\section{ABSTRACT}

The concept of intermediality underwent a deep transformation with the digital turn, when the difference between media became entirely virtual and a continuous communication system superseded the discontinuous analogic system. Does intermediality still make sense in the era of post-media? And, in particular, how do digital natives, with their specific cognitive abilities, perceive intermediality? Can we think of literature in terms of a fluid intermedial relation of writing to other media? And does such an approach help when it comes to teaching literature to digital natives? What are the intermedial products that the creative industries are designing specifically for them? Taking Shakespeare as an eminent example of a writer whose work has been adapted to all kinds of media, this article focuses on the phenomenon of British theatre productions that are conceived to be screened live in cinemas all over the world and presents the results of a pilot experiment devised to investigate the reception of one of these productions by a sample audience of Italian teenagers.

\section{RÉSUMÉ}

Le concept d'intermédialité a connu une transformation profonde avec le tournant numérique, qui a provoqué l'amenuisement des différences entre les médias, jusqu’à les rendre virtuelles, et la supplantation d'un système analogique discontinu par un système de communication continu. Est-ce que l'intermédialité fait encore sens à l'ère post-médiatique ? Comment les enfants du numérique la perçoivent-ils avec leurs habiletés cognitives particulières ? Pouvons-nous penser la littérature au sein d'une relation intermédiale fluide avec d'autres médias ? Une telle approche peut-elle contribuer à l'enseignement de la littérature aux enfants du numérique ? Quels sont les produits intermédiaux que les industries culturelles conçoivent spécifiquement pour eux ? Prenant Shakespeare comme exemple éminent d'un écrivain dont l'œuvre a été adapté pour différents médias, cet article est consacré aux productions théâtrales britanniques qui sont conçues pour être diffusées sur les écrans des cinémas du monde entier. Il présentera à cet effet les résultats d'une expérience lors de laquelle nous avons évalué la réception de ces productions par un échantillon d'adolescents italiens.

NOTE BIOGRAPHIQUE 
Maddalena Pennacchia is Associate Professor of English Literature at Roma Tre University (Department of Foreign Languages, Literatures, and Cultures). She has authored three books, including Shakespeare intermediale (Editoria \& Spettacolo, 2012). She is the editor of Literary Intermediality (Peter Lang, 2007) and co-editor of Questioning Bodies in Shakespeare's Rome (V\&R Unipress, 2010) and Adaptation, Intermediality and the British Celebrity Biopic (Ashgate, 20I4). 